\section{The Buckingham Project}

Sir, - The dictionary description of the word "perspective" suggests the drawing of objects so as to produce the impression of depth and relative distance. This term is then extrapolated in literary terminology to the idea of "giving a true view of events and circumstances" and to "seeing events in proper relative proportion". Sadly I feel the article on "The Buckingham Project" (Ir J Psychol Med 1990; 7: 151-3) fails to live up to its position in the section "Perspectives". While presenting superficially attractive ideas on psychiatric care it fails to provide substantiation for the value of these. At the same time its publication in this format lends ceredence to the ideas, credence that may be wrongly interpreted by the administrators of Health Boards.

Sadly no data is provided on the numbers any types of patients seen, making impossible comparisons with other types of service. Nor is there any description of local demography, though I believe Buckinghamshire does not contain large areas of unemployment, poor housing or Social Class IV and V population. Yet this is quite a labour intensive approach (four teams of 3 or 4 nurses for 35,000 population) which would presumably require even greater levels of staff in inner city Belfast or Dublin. No hard data is advanced to show that this system of care provides better outcome than more traditional models in which the majority of patients are also treated outside hospital. Furthermore, the relevance of screening all referrals with the PSE is unclear as this is not a good instrument for assessing "negative symptoms".

Another aspect of this service that is not clearly justified is the screening of patients presenting with stress responses in the absence of mental disorder. Is there evidence that this leads to a reduction in subsequent illness? If there is, it should be described for our critical appraisal.

Another question not addressed is the possibility of "drift". This may take two main forms. One is the well recognised drift of chronic schizophrenic patients away from their area of origin to inner city areas, thus reducing the local burden of mental health problems. The second involves patients making use of other services, unknown to the local treatment teams.

In conclusion, I think the presentation of this project does not sufficiently emphasise its experimental nature and the lack of factual information on which to properly assess it.

STEPHEN J. COOPER, MD, MRCPsych, Senior Lecturer/Consultant Psychiatrist. The Queen's University of Belfast Department of Mental Health, The Whitla Medical Building, 97 Lisburn Road, Belfast, Northern Ireland, BT9 7BL.

Editor's reply: The category "Perspective" is used to mean "point of view" rather than (necessarily) "true view". A data paper on this subject is awaited.

\section{BOOK REVIEWS}

\section{BOOKS RECEIVED:}

Asylum history - Buckinghamshire County Pauper Lunatic Asylum - St. John's. John Crammer. London: The Royal College of Psychiatrists/Gaskell, 1990. 195pp, $£ 10.00 \mathrm{pb}$. Chronic pain, vols $1 \&$ 2. Thomas W. Miller, ed. Madison, CT: International Universities Press, 1990. 398pp, $\$ 50.00$ (vol 1); 550pp, $\$ 65$ (vol 2). Cognitive therapy in clinical practice - an illustrative casebook. Jan Scott, J Mark G Williams, Aaron T. Beck, eds. London: Routledge, 1989 hb, 1991 pb. 270pp, $£ 10.99$ pb. Dance therapy \& depth psychology the moving imagination. Joan Chodorow. London: Routledge, 1991. $184 \mathrm{pp}, £ 10.99 \mathrm{pb}$. Further learning from the patient - the analytic space and process. Patrick Casement. London: Routledge, 1990. $197 \mathrm{pp}, £ 25 \mathrm{pb}$. Hypnagogia - the unique state of consciousness between wakefulness and sleep. Andreas Mavromatis. London: Routledge, $1991 \mathrm{pb} .375 \mathrm{pp}, £ 12.99 \mathrm{pb}$. Illness in the analyst implications for the treatment relationship. Harvey Schwartz, AnnLouise Siver, eds. Madison CT: International Universities Press, 1990. $362 \mathrm{pp}, \$ 42.50$. Instinctual stimulation of children, vol 1, clinical findings, vol 2, clinical cases. John Weil. Madison, CT: International Universities Press, 1989. \$30 (vol 1), \$45 (vol 2). Melanie Klein vol I: first discoveries and first system, 1919-1932. Jean-Michel Petot. Madison CT: International Universities Press, 1990 . 325pp, $\$ 40.00$. Personality and disease. Howard S Friedman, ed. Chichester: John Wiley \& Sons, 1990. 333pp, £28.30. Psychological \& Psychiatric problems in men. Joan Gomez. London: Routledge, 1991. 136pp, $£ 25.00 \mathrm{hb}$. Sounds from the bell jar - ten psychotic authors. Gordon Claridge, Ruth Pryor, Gwen Watkins. Basingstoke, Hants: MacMillan, 1990. 272pp, £35.00. Stoke Park Publications (1930-1990) - Mental Handicap. J Jancar, Bristol: Stoke Park Hospital, 1990. 56 pp. The anxiolytic jungle: where next? David Wheatley, ed. Chichester: John Wiley \& Sons, $1990.232 \mathrm{pp}, \mathfrak{1} 47.50$. The closure of mental hospitals. Peter Hall, Ian F Brockington, eds. London: The Royal College of Psychiatrists/Gaskell, 1991. 160pp, £7.50. The human core - the intrapsychic base of behaviour, vol 1 , action within the structural view, vol 2, from anxiety to integrity. Leo Rangell. Madison, CT: International Universities Press, 1990. 478pp (vol 1), $501 \mathrm{pp}$ ( vol 2), $\$ 60$ each. The search for the self -selected writings of Heinz Kohut; vol 3. Paul Ornstein, ed. Madison, CT: International Universities Press, 1990 400pp, $\$ 55.00$.

\section{The Irish body snatchers.}

John Fleetwood. Dublin: Tomar, 1989. 141 pp, IRf4.95.

This catchy title for a book written by a famous Dublin general practitioner, John Fleetwood Snr., is sure to attract the attention of readers with any interest in the macabre. Much has been written on 'resurrectionism' over the years, but nothing with as much local interest as this one.

Most of us in Dublin have noticed the towers on the walls surrounding Glasnevin Cemetery. These housed men who were on the lookout for 'sack-'em ups'. The latter was a name applied to grave-robbers who usually carried away their material in sacks. Doctors, especially in the 18th century, paid handsomly for fresh, and sometimes not so fresh cadavers. Nor was the trade confined to local anatomy schools and budding surgeons. A strong export trade existed in Ireland for many years.

Grave-robbing created fear and panic in everyone. Even the perpetrators and dissectionists had nightmares lest they themselves would fall prey to their colleagues and students eventually. Various ploys, such as well paid guards and weighted coffins, were employed in order to impede the progress of 'carcase merchants'. They were often unsuccessful.

Parts of bodies (forerunners of modern transplant surgery) were equally competed for by sack-'em ups. Teeth and hair were very much in demand by the living! During the Peninsular War some unfortunate soldiers had their teeth pulled on the battlefield even before they were dead.

As gruesome as this all seems today there seems little doubt that our profession would have advanced little only for the toil and dedication of body snatchers. The trade died with the advent of legalised aquisition of corpses. Where it really got out of hand was when traders couldn't wait for material and helped people on their way to the hereafter. At one time the only legal supply of bodies came from the scaffold. Asylums were often guilty of improving their finances by handing over their dead to anatomists.

Dr. Fleetwood handles his material with relish. There are flashes of humour throughout this very readable book. The only criticism which I have is that most of the book depends on non-Irish history. This was obviously due to the paucity of recorded material in Irish archives. Nevertheless, every doctor and medical student should have a copy which they could dig into from time to time. Brian O'Shea Consultant Psychiatrist, Eastern Health Board. 